\title{
LEAF SURFACE CHARACTERISTICS OF DIFFERENT CROPS AND WEEDS - DEVELOPMENT OF A COMPREHENSIVE DATABASE
}

\author{
A.K. PATHAN \\ Plant Protection Chemistry $_{N Z}$ PO Box 6282, Rotorua, New Zealand \\ Corresponding author: amin.pathan@ppcnz.co.nz
}

Leaf surfaces provide an important interface for various physical, biochemical, physiological, biological and ecological processes. Different pathogens, pests and pesticides interact with leaf surfaces differently. It is important to have a better understanding of diverse leaf surface characteristics and the nature of surface-mediated interactions with pathogens, pests and pesticides. Such knowledge has assisted $\mathrm{PPC}_{\mathrm{NZ}}$ to devise improved formulation and application strategies to enhance efficiency of pesticide sprays to a range of crops. $\mathrm{PPC}_{\mathrm{NZ}}$ is developing a database of leaf and fruit surface characteristics of major crop and weed species. Leaf surface information at the macroscopic (e.g. roughness arising from size, density, alignment and distribution of stomata and trichomes) as well as microscopic scale (e.g. roughness arising from the structure and organisation of wax crystals) are incorporated in the database. Static contact angles of aqueous acetone droplets $(20 \%$ and $50 \% \mathrm{v} / \mathrm{v})$ on plant surfaces are provided as an indicator of surface wettability. The inclusion and use of fractal dimensions of different leaf surfaces and canopies as a numerical index representing surface roughness and canopy complexity, respectively, are also being investigated.

\section{IMPACT OF REARING METHOD ON GENETIC VARIATION IN A BIOLOGICAL CONTROL AGENT, HEATHER BEETLE}

\author{
H.M. HARMAN ${ }^{1}$, B.S. WEIR ${ }^{1}$ and S.V. FOWLER ${ }^{2}$ \\ ${ }^{1}$ Landcare Research, Private Bag 92170, Auckland, New Zealand \\ ${ }^{2}$ Landcare Research, P.O. Box 96, Lincoln, Canterbury, New Zealand
}

Corresponding author: harmanh@landcareresearch.co.nz

The manner in which herbivorous insect biocontrol agents are reared before release into new environments may impact on their ability to establish and reach population levels that are effective in controlling their host plant. Genetic bottlenecks may reduce genetic variability lowering potential for agents to adapt to the variety of environments throughout the target weed's range. Artificial conditions may select for laboratory-adapted populations that have difficulty establishing or achieving high population increase in the natural environment. Heather beetle (Lochmaea suturalis) was first introduced to New Zealand in 1992 as a biocontrol for heather (Calluna vulgaris), an environmental weed covering large tracts of land in the Central North Island. In its native range in north-west Europe population outbreaks can cause high levels of damage to heather stands. Imported beetles were line-reared for several generations in quarantine to eliminate a protozoan parasite before stocks were cleared for release. Subsequent releases in many locations in Tongariro National Park have resulted in poor levels of establishment and population growth. Concern that line-rearing has adversely impacted on genetic variability has led to development of microsatellite markers for DNA studies comparing genetic diversity in beetles from line-reared stocks and the native range. 